\title{
African Sounds in the American South: Community Radio, Historically Black Colleges, and Musical Pan-Africanism
}

\author{
Joshua Clark Davis \\ University of Baltimore
}

One night in the early 1970s, Donald Baker received a call for help from a listener. Baker was hosting his regular show on WAFR-FM in Durham, NC, a town of 100,000 residents with a declining tobacco and textile economy. The sole Black-owned radio station in Durham, WAFR occupied the second story of a former Masonic temple on Pettigrew Street in the heart of Hayti, the city's historic Black business district. The caller was throwing a house party that night but didn't have a record player. Baker-known on the air by his adopted Kiswahili name Mwanfunzi Shanga Sadiki-usually played a mix of jazz, Latin, and soul, but this night he tried something different.

The next day the listener called back. The music Baker played had astonished him and his friends. It was funky, filled with heavy dance rhythms and nearly endless trumpet, saxophone, and keyboard vamps - almost like some songs by James Brown's supporting group, the J.B.'s. But the caller and his friends had never heard anything like it before. At more than ten minutes long, the songs were virtual marathons featuring call-and-response vocals that barely sounded like English. Some lyrics weren't in English at all. Still, the music had been perfect for their party. The listener desperately wanted to know what they had heard. Baker informed the listener he'd played several albums by the so-called African James Brown, the Nigerian artist Fela Ransome Kuti (Baker 2010; Baker 1995; Akinwole 2010; Akinwole 1995).

In exposing local listeners to Kuti, WAFR was one of a number of noncommercial institutions in the American South that celebrated African music and musicians from the 1950s to the 1980s. The station's call letters stood for Wave Africa because, as station cofounder Obataiye Akinwole explained, "we wanted to have our heritage in our name" (Akinwole 1995). Indeed, the sounds of African artists reverberated from the control booths of the South's noncommercial Black radio stations - not only WAFR, but also WVSP in tiny Warrenton, NC, and WRFG in Atlanta. These stations 
promoted African music as part of their cultural and political missions. African music also found eager audiences at southern Historically Black colleges and universities (HBCUs) and appealed particularly to civil rights, Black Power, and Pan-African anticolonial activists. The African-American audience for African music in these years thus represents a prehistory of sorts of the "world music" phenomenon that emerged in the 1980s. More importantly, Black American Pan-Africanists who embraced African music force us to reconsider the common interpretation that "world music" audiences have, by definition, embraced a politics of neo-colonialism and cultural imperialism (Guilbault: 41; Garofalo; Goodwin and Gore). Activists and noncommercial institutions that spread African music throughout small and medium-sized towns of the American South also offer a surprising counterpoint to the myth of commercial urban elites monopolizing the dissemination of global Black music. Rather than promoting a world music paradigm, however, Black Americans advanced what I call "musical panAfricanism," namely, the belief that African music could strengthen cultural bonds between Africans and Black Americans and even contribute to their interconnected struggles for equality and liberation throughout the diaspora.

HBCUs have long represented some of the South's most fertile music scenes. By the twentieth century, most HBCUs had their own music departments, choral groups, and marching bands, as well as competing bands organized by students. Commercially successful performers such as the Commodores, Donny Hathaway, Roberta Flack, and Gil Scott-Heron launched their careers while students at HBCUs, while countless other bands at HBCUs produced records without achieving commercial success. The schools, most of which were in the South, were also hotbeds of popular music fandom. Students regularly invited major Black acts to perform on campus, and they patronized Black-owned record stores and nightclubs off campus. Finally, HBCUs were vital to the global circulation of Black music, as they brought African-American students and faculty into contact with other cultures and had also exposed audiences abroad to Black performers like the Fisk Jubilee Singers as far back as the 1870s.

HBCUs facilitated African and African-American interactions in particular (Minter: 19-22). In 1950, Nigerian student Michael Olatunji enrolled at one such college, Morehouse University. In Atlanta, Olatunji visited local Black and White churches, where he gave lectures on Africa and played a Nigerian drum for congregants. He also participated in a youth radio show on Atlanta's WERD, the country's first African-American owned radio station ("Youth Forum"). Michael sang with the school's glee 
club, eventually lectured at HBCUs throughout the South ("Nigerian"), and was even elected senior class president. After graduating, Olatunji moved north to pursue a Ph.D. at New York University. In 1958, he drummed with a band for a short-lived show at Radio City Music Hall called African Drum Fantasy.

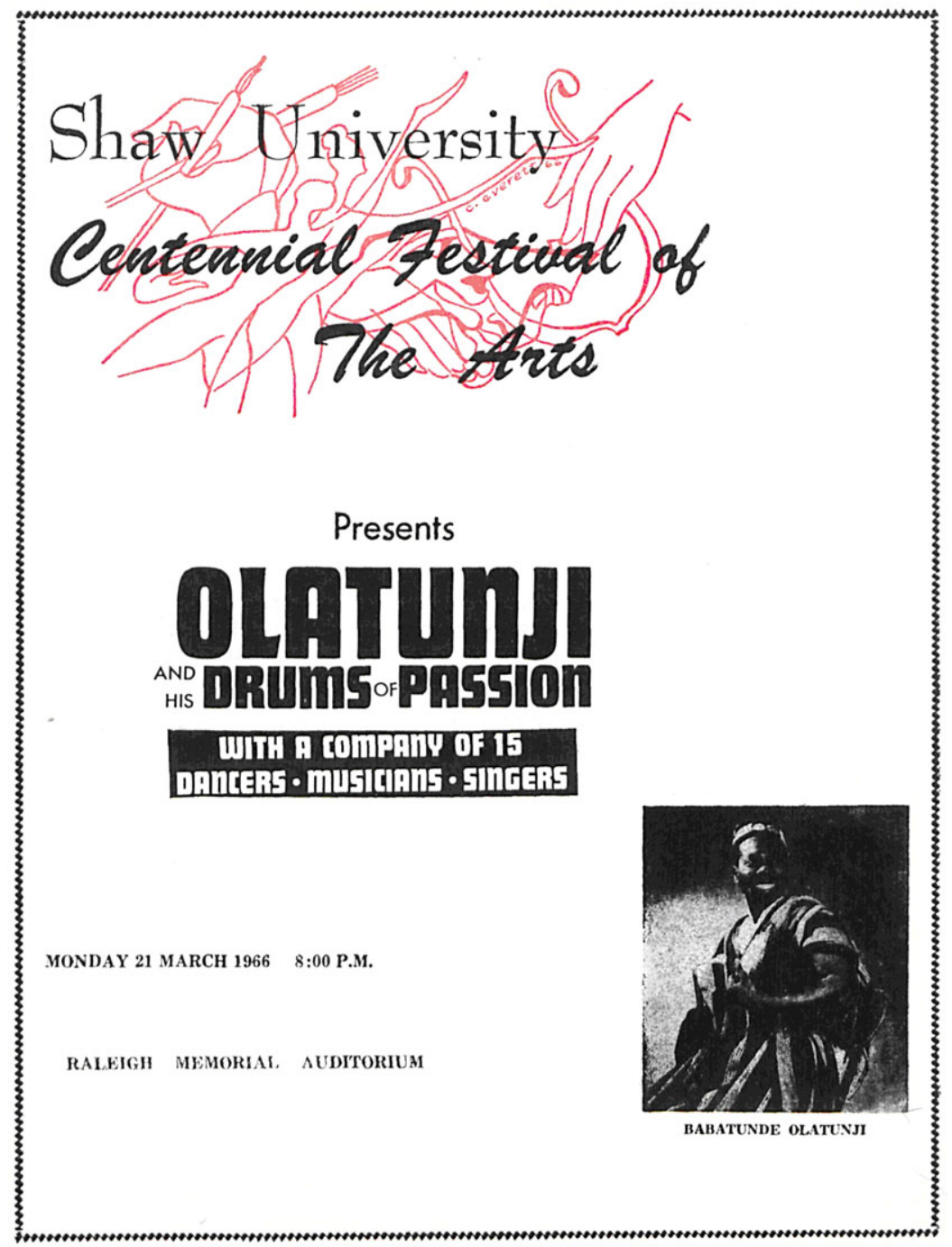

Figure 1: Advertisement for Babatunde Olatunji Concert at Shaw University, Raleigh, North Carolina, 1966.

In 1959, Michael Olatunji released the studio album Drums of Passion for Columbia Records under the name Babatunde (Figure 1). The 
album featured a pastiche of West African "talking drum" styles with Yoruba vocals and sparse instrumentation. Olatunji's band kept a brisk pace throughout the album, with many songs clocking in at 120 beats per minute or more. The album's liner notes, credited to Olatunji and his brother Akin Akiwowo, described Drums of Passion as "a danceable album... [and] probably the first African album recorded in stereophonic sound in the United States." The brothers described the album as an act of folkloristic preservation, a recording of "the remnants of 'primitive' folk music before its gradual disappearance from a fast-changing culture and continent" (Olatunji and Akiwowo). Babatunde's Black global ensemble of musicians from Nigeria, the US, and the Caribbean blended various West African drumming styles in a manner that anticipated what one scholar would describe decades later as world music's "attempt to banalize difference" (Guilbault: 41). Indeed, the sounds and performers on Drums of Passion made it unlike virtually any studio album ever released by a major American recording label (Olatunji: 138).

Drums of Passion's release marks year zero for African popular music's commercial reception in the US. Unlike field recordings of African musicians on labels like Folkways Records, Olatunji's debut was an African immigrant's reinterpretation of West African drumming styles released on a major commercial label for a primarily American audience. Three years later, in 1962, the South African performers Miriam Makeba and Hugh Masekela released their own debut albums on RCA and Mercury, respectively. They also performed at HBCUs across the South and openly criticized the South African apartheid regime ("The Inquiring Reporter"; "Shaw University"; "Whirlwind of Concerts"; Redmond: 236-247; Walters: 376). The rise of Olatunji, Makeba, and Masekela reflected and stimulated Black Americans' growing interest in Africa (Feld: 148). The continent's ever-multiplying anticolonial struggles also drove this interest; in 1960 alone, no fewer than seventeen African nations gained independence. Meanwhile, Makeba and Masekela's careers in the US unfolded amid rising awareness of the injustice of South African apartheid, due in part to Lionel Rogosin's 1959 film Come Back, Africa, which briefly featured Makeba, as well as events like the Sharpeville Massacre and the awarding of the Nobel Peace Prize to Albert Luthuli, both in 1960.

The Civil Rights movement and the nascent revival of PanAfricanism, as seen in publications such as Shirley Graham DuBois' Freedomways, also piqued African-Americans' curiosity about Africa. "The interest of American Negroes in Africa is of deep and partisan 
intensity," the journal declared in a special issue about the continent in 1962. "The new life processes at work in Africa, the struggles unfolding and continuing ... all this inspires and instructs American Negroes in the struggle against segregation and discrimination here, and in more precisely defining the pattern of our own goals of freedom" ("New Image").

Indeed, a number of African and African-American musicians sought to bring attention to campaigns for Black freedom on both sides of the Atlantic. Makeba, for instance, played benefit shows alongside calypso star Harry Belafonte for the Southern Christian Leadership Conference ("Harry Belafonte"; "SCLC Convention"). Meanwhile, politically conscious jazz musicians began to celebrate African themes and feature African musicians in their recordings (Kelley). In 1960, Olatunji played on Randy Weston's Uhuru Afrika album and on “Tears for Johannesburg," Max Roach's anti-Apartheid piece honoring Sharpeville Massacre victims on We Insist! Freedom Now Suite. Olatunji's most important musical benefactor, however, was the North Carolina native and saxophonist John Coltrane, who penned such African-themed pieces as "Dakar" and "Tunji," an homage to his Nigerian friend (Olatunji: 8, 155-157).

By the end of the 1960s, many civil rights and Black Power activists came to embrace Pan-Africanism. Pan-Africanists maintained that all the continent's descendants throughout the diaspora shared a cultural heritage and history of struggle, which in turn obligated them to work collectively towards political, social, and cultural self-determination and especially the decolonization of Africa (Minter; Walters: 47-50). One of the most remarkable communities of Pan-Africanists in the US was in North Carolina. In 1969, Howard Fuller (later Owusu Sadaukai) led activists in Durham in establishing Malcolm X Liberation University, the nation's only college devoted to Black Studies and Pan-Africanism. Sadaukai also chaired the first annual African Liberation Day, an event that drew roughly 50,000 protesters to Washington, D.C. in 1972 (Minter: 126). MXLU moved to Greensboro in 1970, where it worked closely with the Student Organization for Black Unity (SOBU), a national network of Pan-Africanist college and high school students led by local activist Nelson Johnson. SOBU organized campaigns against institutional racism and police brutality throughout the US, provided financial aid to independence movements in Africa, and sponsored cultural events. When SOBU hosted Makeba and her husband Stokely Carmichael in Greensboro in 1971, for instance, its African World newspaper proudly declared that Makeba's band of "two Guineans, a Puerto Rican, and a brother from Pittsburgh ... embodies the pan-African spirit" (Coleman: 9). Indeed, 
both MXLU and SOBU's work brought Pan-Africanists from around the world to visit, live, and organize in North Carolina.

African music and political Pan-Africanism also converged at a pair of Black community radio stations in North Carolina in the 1970s. Radio had aided anticolonial struggles in Africa since the 1950s, but American commercial stations, even Black-owned ones, largely avoided radical politics for fear of alienating advertisers (Fanon: 82-97; Brennan: 173-195; Ward). By the second half of 1960s, activists in the Civil Rights and Black Power movements came to view commercial Black-oriented radio stations, the vast majority of which were White-owned, as failing to serve Black communities' larger interests. Activists in some cities even organized campaigns to pressure local stations to hire more AfricanAmericans and increase their news coverage of Black communities (Media and the Movement; Coleman, "Black Radio"). New possibilities for Black radical and community programming emerged, however, with the federal Public Broadcasting Act of 1966, which significantly increased funding for noncommercial radio stations. By the 1970s, Black activists were producing political programming at multiracial noncommercial stations like WRFG in Atlanta, WPFW in Washington, and KPOO in San Francisco.

In Durham, activists operated WAFR, the first independent noncommercial radio station controlled by African-Americans, from 1971 to 1976. WAFR featured extensive reporting on local news from Durham's Black community as well as national and international news from throughout the African diaspora. "We wanted to hear about the truth about what was happening to our people here in America and about the rest of the world," station cofounder Obataiye Akinwole explained, including "things that were happening in Africa - colonialism, forced servitude, the works" (Akinwole 1995). The "truth" that WAFR broadcasted was not only news, however, but also musical Pan-Africanism. In their original application for a broadcasting license, the station's staffers proposed several regular African-themed shows, including "African Tribal Sounds," devoted to "music of Africans-Ido, Hausa, and Maudingo - and the "men of the drums." Another show on rhythm and blues "would trace the origins of this form of music through the Calypso, the Mambo, the Samba, and African tribal music" ("Community"). Indeed, the station made a "conscious decision to play nothing but Africanbased music," ranging from jazz to soul to artists like Makeba, Olatunji, and Fela. In so doing, Akinwole explained, WAFR sought to build a "sonic bridge" between Africans and Black Americans that functioned as a vehicle for "messaging and fighting for our freedom" (Akinwole 2013). 
Another Black-led community radio station that promoted musical pan-Africanism was WVSP, located in the tiny rural town of Warrenton, NC. Despite its geographic isolation, WVSP broadcast at 100,000 wattsthe maximum power allowed by the FCC - into a wide reception area including the Research Triangle, eastern North Carolina, and parts of southern Virginia. Valeria and Jim Lee, an African-American couple who had actively participated in the region's Black Power and pan-Africanist movement, founded the station in 1976 and managed it until shuttering it in 1986. The station aired programming produced by local citizens from Warrenton and the surrounding region, as well as progressive local, national, and international news. WVSP regularly aired reports from the Africa News Service, for instance, the first syndicator of African news in America, which was based in Durham and led by antiapartheid activists Tami Hultman and Reed Kramer (Minter:134-138).

WVSP also sought to affirm Black Southerners' African heritage by playing a wide range of music from all over the diaspora. "To be Black and a part of the Rural South and not have access to the blues or jazz or African music," Valeria Lee argued, "was to be denied access to our culture." WVSP sought to "expand peoples' sense of what's possible musically," Jim Lee explained. "There were people in our audience who had never heard reggae or African music" before listening to WVSP, but "they ended up liking it" (Adler; Lee). WVSP offered listeners "entertainment that was activism," music by artists like Makeba and Kuti, who "were not just entertainers, [but] were political people, with messages, [who] sang about the human condition" (Lee). Like WAFR, WVSP broadcast news and music from the diaspora as part of a larger vision of political and musical Pan-Africanism.

WAFR and WVSP proudly exposed the region's listeners to African music in the 1970s and early 1980s, but commercial radio stations rarely played the continent's musicians. The few African artists to appear on the Billboard charts - including Makeba, Olatunji, Masekela, the Ghanian group Osibisa, and the Cameroonian artist Manu Dibango - did so briefly and usually at low positions. Fela, the so-called James Brown of Africa, never even had a song or album that charted in America in his lifetime (Whitburn 2006; Whitburn 2010).

The second half of the 1980s marks a turning point in the history of African music's reception in the US. In 1986, the South African group Ladysmith Black Mambazo joined Paul Simon on the album Graceland, reaching the third spot on the Billboard albums chart. Masekela and Makeba even joined Simon and Ladysmith Black Mambazo for the album's tour. Yet 
some Black critics condemned the album and tour for defying a cultural boycott of South Africa initiated by the African National Congress in 1982. Antiapartheid activists, including Pan-Africanist scholar Molefi Asante, picketed the tour in Philadelphia and charged it with white expropriation of African music. As one protester explained, "We reject Paul Simon's trying to capture the South African Sound and market that sound." Anecdotal accounts suggested that the overwhelming majority of Simon's concert attendees were white (Dove-Morse; Baillou). In response to the controversy, one African expatriate lamented that commercial African-American radio rarely played African music, while another attributed Graceland's success to an increasing "Yuppy consumption of exotic music" (Mahoso; Fempong).

Graceland's success clearly demonstrated that many American listeners could embrace African musicians regardless of their commitment to anticolonialism and Pan-Africanism. The same year as Graceland's release, a group of British recording labels led by Island Records held meetings in London to devise a strategy for selling non-American and non-European music. The result was the creation of the "world music" genre for marketing Asian, Latin American, and African music in the US and Europe. In 1991, the Grammy Awards followed suit, establishing a Best World Music Album category (Fairley: 6-9; White: 2-3; Barz: 649).

Decades before US and UK corporate record labels capitalized on African music, however, Black activists and noncommercial institutions had worked extensively to disseminate African music in the American South. Indeed, Pan-African and Black Power activists' embrace of African music belies claims that fans of so-called "world music" invariably reinforce neocolonialism and cultural imperialism (Guilbault: 41; Garofalo; Goodwin and Gore). Yet this article also raises many more questions about AfricanAmerican audiences for African music. First, what effect did the emergence of a corporate, multinational "world music" genre have on the radical political and cultural potential of African music in the US? Along these lines, how can we understand the popular reception of African artists such as Fela Kuti in the US in the last decade? Furthermore, how did Black audiences for African music in the American South differ from those outside the South? Did the sizable communities of African immigrants in such cities as Washington, D.C. and New York, for instance, shape the reception of African music? In conclusion, these questions point to the urgency of further investigating African American listeners not only as fans of African music, but also as key agents of musical globalization in the United States. 


\section{Works Cited}

Adler, Bill. "WVSP: Voices Serving People.” Southern Exposure 9 (1981): 23-25. Print.

Akinwole, Obataiye. Interview. 21 April 1995. Archives of African American Music and Culture, SC 39, Indiana University. Print.

—. Interview with author. 30 July 2013.

- Interview with author. 18 November 2010.

Baillou, Charles. "Graceland Stirs Storm of Protest." New York Amsterdam News. 23 May 1987: 2. Print.

Baker, Donald. Interview with author. 11 November 2010.

Baker, Donald. Interview. 20 April 1995. Archives of African American Music and Culture, SC 39, Indiana University. Print.

Barz, Gregory. "Encountering African Music in History and Modernity." The Cambridge History of World Music. Ed. Philip V. Bohlman. Cambridge: Cambridge UP, 2013. 637-660. Print.

Brennan, James R. "Radio Cairo and the Decolonization of East Africa, 195364." Making a World After Empire: The Bandung Moment and Its Political Afterlives. Ed. Christopher J. Lee. Athens: Ohio UP, 2010. 173-195. Print.

Coleman, Milton. "Black Radio Must Serve the Community-Mobilization Follows Firings." The African World. 2 October 1971: 3, 10. Print.

Coleman, Milton. "Miriam Makeba Visits U.S.: Solid African Base is Most Important." The African World. 27 November 1971: 9. Print.

"The Community Radio Workshop, Inc." WAFR application to the Federal Communications Commission. In author's possession. Undated, circa 1971. Print.

Dove-Morse, Pheralyn. "Simon Concert Weathers Protest Storm." Philadelphia Tribune. 19 June 1987: 8-A. Print.

Fairley, Jan. "The 'Local' and 'Global' in Popular Music." The Cambridge Companion to Pop and Rock. Ed. Simon Frith, Will Straw, and John Street. Cambridge: Cambridge UP. 2001. Print.

Fanon, Franz. A Dying Colonialism. New York: Grove P, 1965. Print.

Feld, Steven. "A Sweet Lullaby for World Music.” Public Culture 12.1. (2000): 145-171. Print. 
Fempong, Kwaku. "The Graceland Concert: An African's Viewpoint.” Philadelphia Tribune. 26 June 1987: Print. 10-A.

Garofalo, Reebee. "Whose World, What Beat: The Transnational Music Industry, Identity, and Cultural Imperialism." The World of Music 35.2 (1993): 16-32. Print.

Goodwin, Andrew and Joe Gore. "World Beat and the Cultural Imperialism Debate." Socialist Review. (July 1990): 63-80. Print.

Guilbault, Jocelyne. "On Redefining the "Local" Through World Music. The World of Music 35.2 (1993): 33-47. Print.

"Harry Belafonte, Show To Play Here Wednesday, June 6." Atlanta Daily World. 13 May 1962: 5. Print.

"Inquiring Reporter." The Bennett Banner. March 1962: 2, 4. <http://library. digitalnc.org/cdm/compoundobject/collection/newspapers/id/15071/rec/1 > .

Kelley, Robin D.G. Africa Speaks, America Answers: Modern Jazz in Revolutionary Times. Cambridge, M A: Harvard UP, 2012. Print.

Lee, Jim. Interview with author. November 16, 2010.

Mahoso, Tafatnona. “The Graceland Tour: An African's Negative View.” Philadelphia Tribune. 14 July 1987: 11-A. Print.

Media and the Movement: Journalism, Civil Rights and Black Power in the American South. 16 April 2014. <http://MediaAndTheMovement.unc.edu>.

Meintjes, Louise. "Paul Simon's Graceland, South Africa, and the Mediation of Musical Meaning." Ethnomusicology (2007): 37-73. Print.

Minter, William, Gail Hovey, and Charles Cobb, Jr. No Easy Victories: African Liberation and American Activists Over a Half Century, 1950-2000. Trenton, NJ: African World P, 2007. Print.

"The New Image of Africa.” Freedomways 2 (Fall 1962): 357. Print.

"Nigerian, Senior at Morehouse Visits Fla." Atlanta Daily World. 2 March 1954: 2. Print.

Olatunji, Babatunde. The Beat of My Drum: An Autobiography. Philadelphia: Temple UP, 2005. Print.

Olatunji, Babatunde, and Akin Akiwowo. Drums of Passion. 1959, Columbia Records, 8210 .

Redmond, Shana L. Anthem: Social Movements and the Sound of Solidarity in the African Diaspora. New York: NYU Press, 2013. 
"SCLC Convention Set For Nashville, Sept. 27-29." Atlanta Daily World. 24 September 1961: 3. Print.

"Shaw University Centennial Festival of the Arts Presents Olatunji and His Drums of Passion." Raleigh, NC: Shaw University, 1966. < http://library. digitalnc.org/cdm/compoundobject/collection/ncmemory/id/35707/rec/12>.

Walters, Ronald. Pan-Africanism in the African Diaspora: An Analysis of Modern Afrocentric Political Movements. Detroit: Wayne State UP, 1993. Print.

Ward, Brian. Radio and the Struggle for Civil Rights in the South. Gainesville: UP of Florida, 2006. Print.

"Whirlwind Of Concerts Attracts Ala. Students." The Chicago Defender. 20 March 1965: A4. Print.

Whitburn, Joel. Joel Whitburn Presents The Billboard Albums. Menomonee Falls, W I: Record Research, Inc., 2006. Print.

—. The Billboard Book of Top 40 Hits. New York: Billboard, 2010. Print.

White, Bob W., ed. Music and Globalization: Critical Encounters. Bloomington: Indiana UP, 2012. Print.

"Youth Forum Organized." Atlanta Daily World. 8 February 1953: 2. Print. 